\title{
建築下層部の壁面後退による街路の空間形状意識について 一街路の空間形状意識に関する研究 その 2 - \\ THE PERCEIVED SHAPES OF THE STREET WITH SETBACK SPACE IN THE BUILDING LOWER PART \\ Perceived shape of street space Part 2
}

松本直司*, 前田吉保**, 石川肇*** Naoji MATSUMOTO, Yoshiyasu MAEDA and Hajime ISHIKAWA

\begin{abstract}
We intend to clarify the perceived shapes of the street with setback space in the building lower part.
Firstly, we made perceptual experiments, using perspectives, and got 12 types of perceived shapes. Secondly, we showed subjects scale models using a visual simulator, and asked them to choose the perceived shapes from the types. Analyzing the results, we found that perceived shapes are related to the physical proportions of the street. Thirdly, we focused on the factors of the street such as frontage, depth, width, and height of building lower part, and got the relation between perceived shapes and these factors.

Finally, using these 4 factors we made a diagram of distinction of these types. The diagram allows us to easily distinguish between perceived shapes.
\end{abstract}

Keywords: lower part setback, perceived shape, scale model, depth, frontage, height of building setback space 下層部壁面後退，空間形状意識，縮尺模型，奥行き，間口，後退部高さ

\section{1.はじめに}

移動空間としての道には，(1)平らな土地に路面のみが存在するも の (2)並木などの樹木や建物等により道の周囲が限定されるもの (3)それらの限定された空間の中に機能的・装飾的意味を持つ装置が 置かれるもの 等の状況が考えられる。都市内の道すなわち街路で は(1)の状況はほとんどなく(2)や(3)の状況となる。(2)は建物等の空間 限定物によって空間形状が決定される。この空間にフラワーポット や街路灯， ベンチといった様々な装置が加えられると(3になる。空 間形状はより細かく，複雑になってくる。

一方, 街路における人間の行為やその利用内容は，そこの人口密 度，用途内容等の立地条件によるところが大きい。しかし，その行 為を受け止める空間の形状も極めて重要である。街路空間と周囲の 環境との関係, 及びその街路自体の空間形状とが満足されたとき に,より充実した行為や利用内容が生み出される。

本稿は前稿蛙1に続くものである。前稿では建物の壁面全層が一部 後退した場合の街路の空間形状がどのように認識されるのかを，道 路幅員，後退空間の間口，奥行き，壁面高さの関係より分析した。 本稿では，都市内で多くの実例が見られる建物の下層部壁面が一部 後退した場合について扱うもので，図 1 に示すような場合につい て, 街路の空間形状がどのように認識されるのかを明確化すること
を目的とする。

具体的には，(1)透視図実験による建物下層部が壁面後退した場 合の街路空間の形状意識の抽出 (2)縮尺模型実験による建物下層 部が壁面後退した街路の物的条件と空間形状意識の関連性の明確化

(3)空間形状意識の判別予測 （4)実在する街路空間においての空 間形状意識の判別と縮尺模型実験による判別予測結果との比較・検 討を行う。

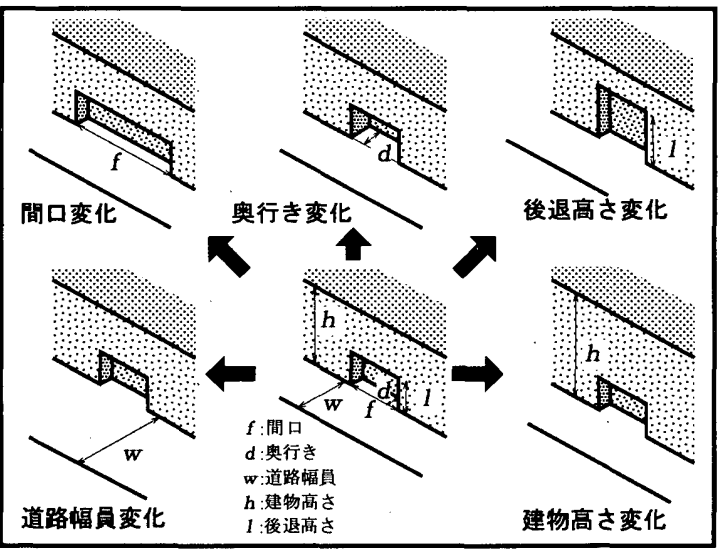

図 1 下層部壁面後退空間の形状変化
* 名古屋工業大学工学部社会開発工学科建築学系 教授・工博

** (侏愛知模型コンサルタント 工修

*** 伊藤建築設計事務所 工修
Prof., Dept. of Architecture, Faculty of Engineering, Nagoya Institute of Technology, Dr. Eng.

Aichi Model Consultant, M. Eng.

Ito Architects and Engineers Inc., M. Eng. 


\section{2. 空間形状意識の抽出}

建物下層部が壁面後退した場合の街路空間の形状意識を，後退部 の奥行き，間口，後退高さを変化させた透視図実験により抽出す る。

\section{1 実験内容}

両側壁面が一様に続く街路空間の壁面下層部の一部を後退させた 実験対象パターンの透視図を被験者に提示した。壁面下層部が後退 しており空間は平面的に捉えられると同時に立体的にも捉えられる と考えられるため，回答用紙には全対象パターンにおいて建物配置 を表した同一の平面図と断面図を示した。被験者には，提示された 透視図の街路空間の形状より捉えられる空閒形状を平面図，断面図 上に感じたままを自由に描かせ，文章で説明を加えさせた。

実験対象パターンは, 図 2 に示す間口 $(f)$, 奥行き $(d)$, 後退高

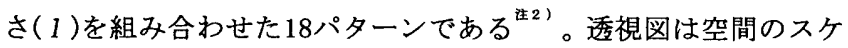
一ル感を出すため視点高さを $1.5 \mathrm{~m}$ とし，人型モデルを配置した。 透視図は 1 パターンずつ被験者から約 $40 \mathrm{~cm}$ 離した位置に置き，順 序効果を排除するために被験者ごとにランダムな順序で提示した。 被験者は名古屋工業大学社会開発工学科学生・大学院生 21 名で, 実 験は1995年7月に実施した。

\section{2 空間形状意識の抽出}

回答結果を集計したところ全体で19の形状意識が得られた。それ らを次の基準により分類した。

(1) 平面形状による分類

(1)空間形状意識に変化があるか。(2)後退空間に道路から分離した空 間が存在するか。(3)街路空間が後退空間により分断されているか。

(2) 断面形状による分類

(1)後退高さ変化により上部壁面を意識するか。(2)その他特別な関係 がみられるか。

図 3 に分類結果を示す。平面形状では $\mathrm{A}$ :一様 $\mathrm{B}$ :膨らみ $\mathrm{C}$ : 分離 $\mathrm{D}$ :迫り出し $\mathrm{E}$ :膨らみ.分離 $\mathrm{F}$ :重なり $\mathrm{G}$ :分断の 7 種類 に,さらに断面形状では I :張り出し部を意識する II:張り出し 部を意識しないの 2 種類にそれぞれ分類され，それらを組み合わ せた計12の空間形状意識が抽出された。

\section{3. 物的条件と空間形状意識}

\section{1 空間形状意識実験（その1）}

下層部壁面後退部の物的条件として間口 $(f)$, 奥行き $(d)$, 後退 高さ／建物高さ $(1 / h)$ の 3 変数を取りあげ，それらを段階的に変化 させた街路空間の空間形状意識を求めることにより物的条件との関 連性を明確化する。

\subsection{1 実験内容}

（1）実験対象パターン

実験対象パターンは，空間形状意識に影響があると考えられる間 ロ( $f)$ を 5 パターン, 奥行き $(d) を 4$ パターンとした。また, 空間 形状意識には断面形状も影響すると考えられるため後退高さ／建物 高さ $(1 / h)$ を 6 パターン加えた。道路幅員 $(w)$ は $9.0 \mathrm{~m}$ (一定)とした。 従って, 実験対象パターンは $5 \times 4 \times 6=120$ パターンである。

(図4)

（2）実験方法

実験対象パターンの街路区間を $80 \mathrm{~m}$ とし，街路空間の端部から

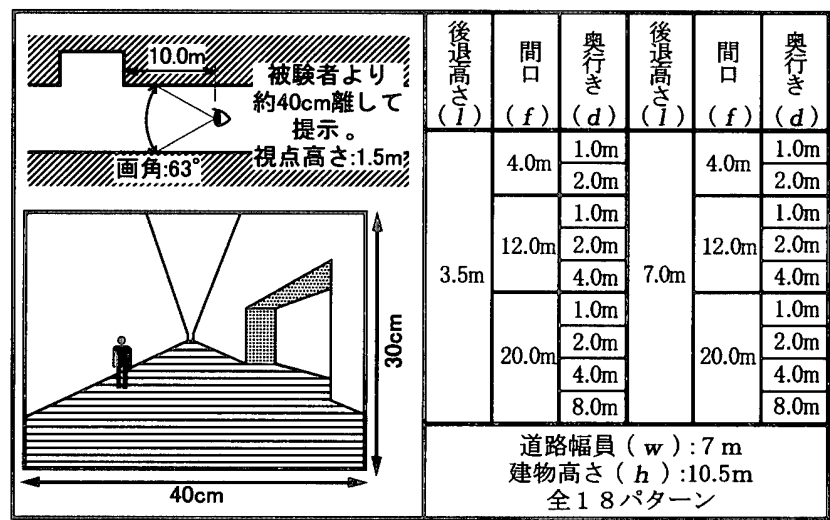

図 2 実験用透視図と実験対象パターン

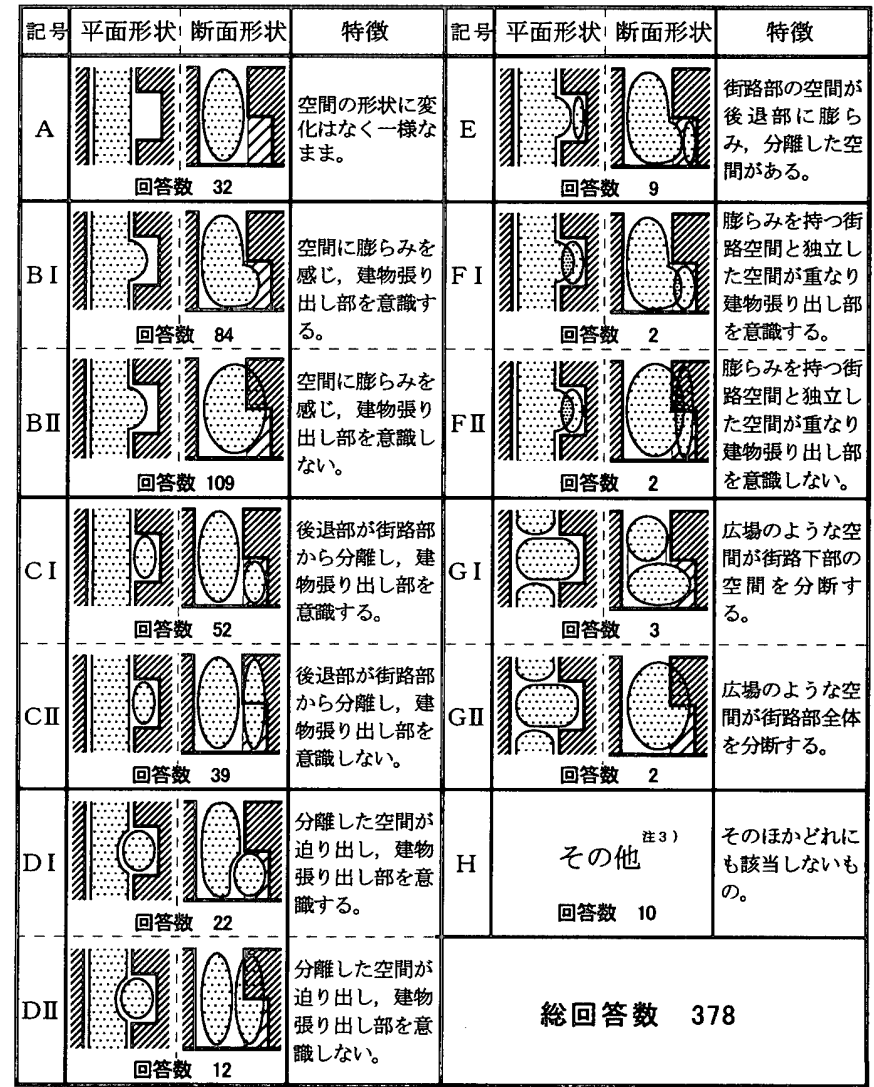

図 3 街路の空間形状意識（建築下層部壁面後退の場合）

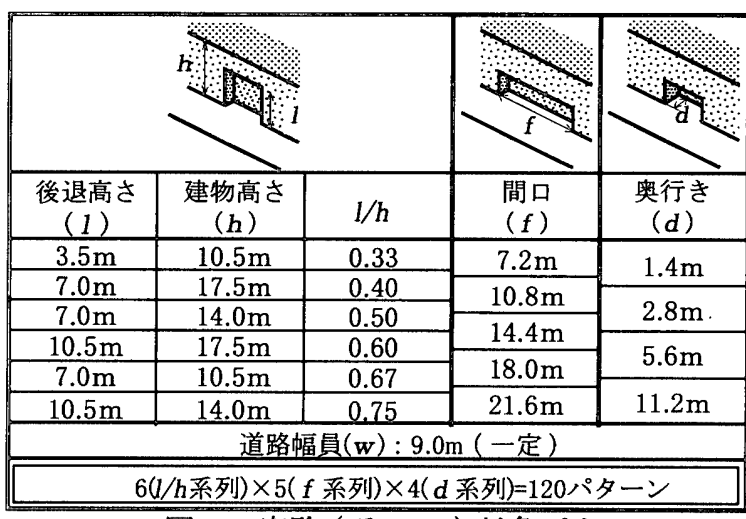

図 4 実験 (その 1 ) 対象パターン

$30 \mathrm{~m}$ に下層部壁面後退空間を配置した $1 / 50$ 縮尺模型を作成し，スケ ール感を出すために人体模型を配置した。実験には, 街路空間内で の歩行を想定し縮尺模型空間内を視点高さ $1.5 \mathrm{~m}$, 街路空間端部か 
ら速度 $80 \mathrm{~m} / \mathrm{min}$ で前進，下層部壁面後退部の手前で停止し後退部を 見回し・見上げた後，さらに前進させた40秒間のVTR映像を空間評価 知覚メディア(シミュレータ $)^{\Downarrow 4)}$ を用いて撮影した映像を用いた。

被験者は名古屋工業大学社会開発工学科学生・大学院生の計15名 で，3名ずっ 5 グループに分けて行った。VTR映像は29インチTV モニターを用いて提示し，実験対象の空間形状が透視図実験により 得られた12の空間形状意識のどれに相当するかを判別させた。実験 対象パターンは被験者グループごとにランダムな順序で提示した。 実験は2000年 6 月 5 日〜同 9 日に実施し，実験時間は各グループと も途中休憩を 1 回とり約1.5時間であった。

\subsection{2 物的条件と空間形状意識の関係}

（1）奥行き変化と空間形状意識

図 5 は奥行き $(d)$ 変化に注目した空間形状意識別の判別回数 ${ }^{\text {\#5 }}$ を示している。 $\mathrm{A}$ (一様)は $d=1.4 \mathrm{~m}$ の判別回数が最も多く，奥行き が小さい場合に判別される。B(膨らみ)は $d=1.4,2.8 \mathrm{~m}$ の判別回数 が多く，奥行きが小さい場合に判別される。 $\mathrm{C}$ (分離)， $\mathrm{D}$ (迫り出 し), $\mathrm{E}$ (膨らみ・分離), $\mathrm{F}$ (重なり)は奥行きの最も小さい $d=1.4 \mathrm{~m}$ の場合はほとんど判別されず $d=2.8,5.6,11.2 \mathrm{~m}$ の場合にそれぞ れ多く判別されている。 $\mathrm{G}$ (分断)は $d=11.2 \mathrm{~m}$ の判別回数が多く, 奥行きが大きい場合に判別される。

\section{(2) 間口変化と空間形状意識}

図 6 は間口 $(f)$ 変化に注目した空間形状意識別の判別回数を示し ている。 $\mathrm{A}$ (一様)は $f=7.2 \mathrm{~m}$ 判別回数が最も多く，間口が小さい ほど判別される。B(膨らみ)はB I では間口が大きいほど判別回数 が多い。B II は間口の大きさが変化してもほぼ同数の判別回数であ る。C(分離)は $f=7.2 \mathrm{~m}$ の判別回数が多く, 特にC II でこの傾向が 顕著である。D(迫り出し)はD I では $f=7.2 \mathrm{~m}$ の判別回数が少ない が， $\mathrm{D}$ II では逆に $f=7.2 \mathrm{~m}$ 判別回数が多い。 $\mathrm{E}$ (膨らみ・分離)， $\mathrm{F}$ (重なり)は間口の値が変化してもほぼ同数の判別回数である。G (分断)は $f=21.6 \mathrm{~m}$ の判別回数が多く, 間口が大きいほど判別され る。

\section{（3）後退高さ／建物高さ変化と空間形状意識}

図 7 は後退高さ／建物高さ $(l / h)$ 変化に注目した空間形状意識別の 判別回数を示している。A(一様)は $I / h$ に拘わらずほぼ同数の判別回 数である。A以外は空間形状意識の断面形状別に特徴が表れてい る。 $\mathrm{E}$ (膨らみ・分離), $\mathrm{F} \mathrm{I}$ (重なり), $\mathrm{G} \mathrm{I}$ (分断)はl/hに拘わらず ほぼ同数の判別回数だが，B I (膨らみ)，C I (分離)，D I (迫り出 し)は $1 / h=0.33,0.40,0.50$ の判別回数が多い。B II , C II，D II， F II , G II は $1 / h=0.60,0.75$ の判別回数が多い。l/h=0.60，0.75は 後退高さ $(1)$ が $10.5 \mathrm{~m}$ の場合であり，後退高さが高いほど II（張り 出し部を意識しない) が判別される。

(4) 空間形状意識の判別傾向

平面形状に注目すると $\mathrm{A}$ (一様)は奥行き，間口がともに小さい場 合に判別される。B(膨らみ)は奥行きが小さく間口が大きい場合に 判別される。 $\mathrm{G}$ (分断)は奥行き，間口がともに大きい場合に判別さ れる。 $\mathrm{C}$ (分離)， $\mathrm{D}$ (迫り出し), $\mathrm{E}$ (膨らみ・分離)， $\mathrm{F}$ (重なり)は奥 行き, 間口変化に関して若干差がみられるがほぼ同様の判別傾向を もつ。また，断面形状に注目すると I は $I / h=0.33,0.40,0.50$ の場 合に判別され, 逆にII $\mathrm{I} / \mathrm{h}=0.60,0.75$ の場合, つまり後退高さが $10.5 \mathrm{~m}$ 場合に判別される傾向がある。

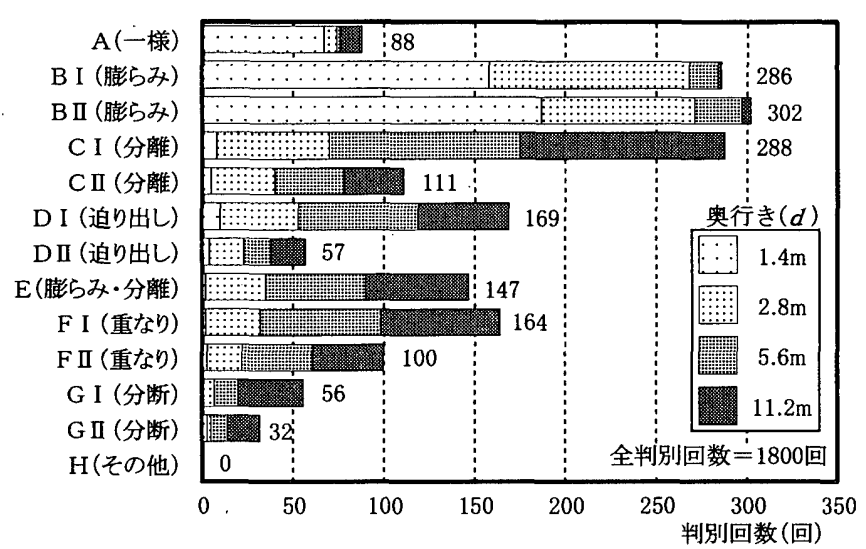

図 5 空間形状意識別の判別回数 (奥行き変化)

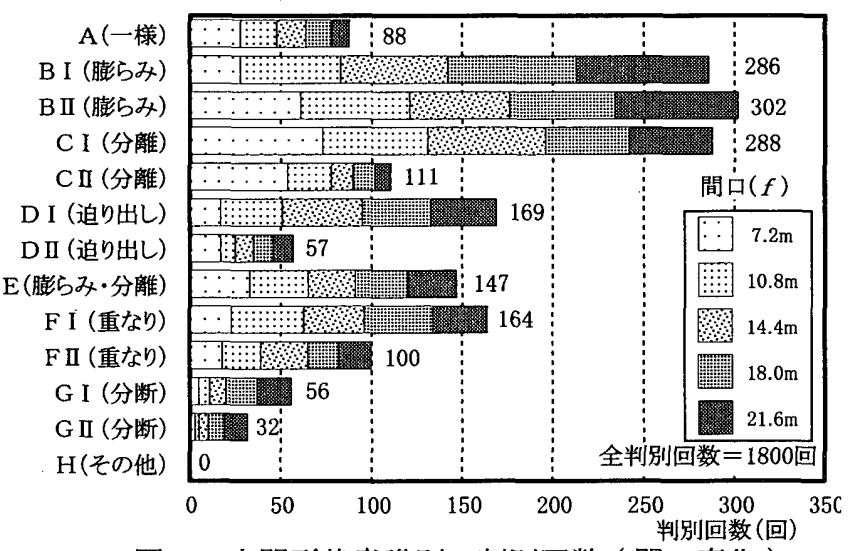

図 6 空閒形状意識別の判別回数（間口変化）

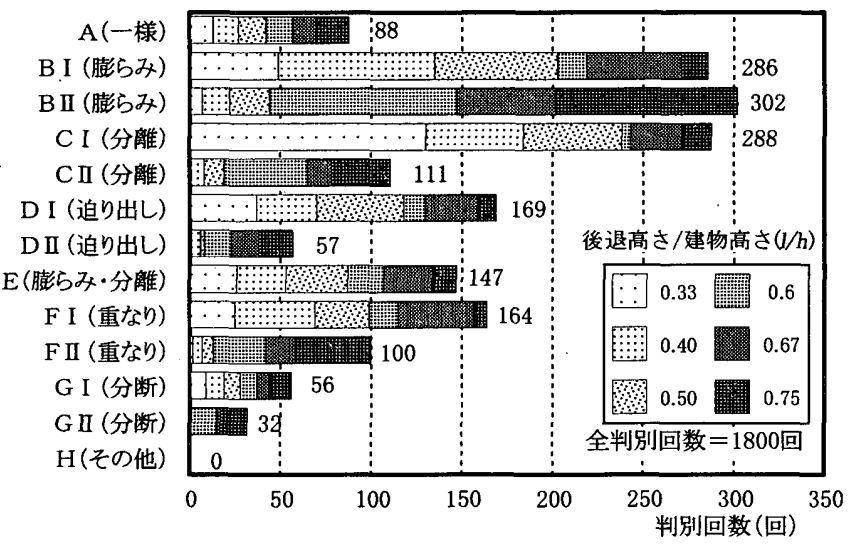

図 7 空間形状意識別の判別回数(後退高さ／建物高さ変化)

\section{2 空間形状意識実験 (その 2 )}

$\mathrm{C}$ (分離)， $\mathrm{D}$ (迫り出し)， $\mathrm{E}$ (膨らみ・分離), $\mathrm{F}$ (重なり)の判別傾 向は類似しており，これらの空間形状意識は非常に類似したもので あると考えられる。そこで $\mathrm{C}$ (分離)が若干変化した形状意識である $\mathrm{E}$ (膨らみ・分離)， $\mathrm{F}$ (重なり)を $\mathrm{C}$ と見なし選択肢から除くことに より空間形状意識の判別予測が可能になると考えられる。従って, 空間形状意識の平面形状 $\mathrm{A} \sim \mathrm{D}$ 及び $\mathrm{G} の 5$ 種類, 断面形状で I , II の 2 種類，計 9 種類の空間形状意識を選択肢とした縮尺模型実験を 続いて行う。

\subsection{1 実験内容}

(1) 実験対象パターン

実験対象パターンは，間口(f)は7.2mを除いた 4 パターン，奥行 
き(d)は0.7mを加えた 5 パターンとした。後退高さ/建物高さ $(\mathrm{l} / \mathrm{h})$ は0.75を除いた 5 パターンとした。さらに，空間形状意識に影響が あると考えられる道路幅員 (w)を 3 パターン加えた ${ }^{\text {生6) }}$ 。従って， 実験対象パターンは $4 \times 5 \times 5 \times 3=300$ パターンである。(図 8)

(2) 実験方法

パターン数の増加に伴い被験者の負担が増加する。そこで縮尺模 型空間のVTR映像の撮影開始点を街路端部より $10 \mathrm{~m}$ の位置とし， VTR映像を 30 秒に短縮した。その他は前節と同様の撮影方法であ る。

被験者は名古屋工業大学社会開発工学科学生・大学院生の計 15 名で 1 名ずつ行った。実験対象パターンは被験者ごとにランダムな 順序で提示した。実験は2000年 9 月 18 日〜同22日に実施し，実験時 間は各被験者とも途中休䕀を 1 回とり約 2 時間であった。

\subsection{2 物的条件と空間形状意識の関係}

図 9 は各物的条件別に空間形状意識を判別回数で示したものであ る。以下に, 物的変数ごとの空間形状意識との関係を考察する。

（1）奥行き変化と空間形状意識

空間形状意識の平面形状別に注目すると $\mathrm{A}$ (一様)は $d=0.7 \mathrm{~m}$ の判 別回数が多く，奥行きが小さい場合に判別される。B(膨らみ)は $d$ $=1.4 \mathrm{~m}$ の判別回数が多い。C (分離) $1 d=11.2 \mathrm{~m}$ の判別回数が多 く，奥行きが大きい場合に判別される。 $\mathrm{D}$ (迫り出し)は $d=2.8$, $5.6,11.2 \mathrm{~m}$ の判別回数が多い。 $\mathrm{G}$ (分断)は $d=5.6,11.2 \mathrm{~m}$ の判別回 数が多く，奥行きが大きい場合に判別される。

（2）間口変化と空間形状意識

$\mathrm{A}$ (一様) は間口の大きさが変化してもほぼ同数の判別回数であ る。 $\mathrm{B}$ (膨らみ)は $f=18.0,21.6 \mathrm{~m}$ 判別回数が若干多く，間口が大 きい場合に判別される。 $\mathrm{C}$ (分離)は $f=10.8 \mathrm{~m}$ の判別回数が多く, 間口が小さい場合に判別される。C I よりC II の方がこの傾向が顕 著である。D(迫り出し)は D I は $f=10.8 \mathrm{~m}$ 判別回数が若干少な いがD II は逆に $f=10.8 \mathrm{~m}$ の判別回数が多い。G(分断)は $f=18.0$, $21.6 \mathrm{~m}$ の判別回数が多く，間口が大きい場合に判別される。

（3）道路幅員変化と空間形状意識

$\mathrm{A}($ (一様)， $\mathrm{C}$ (分離)は $\mathrm{w}=11.0 \mathrm{~m}$ の判別回数が多く，道路幅員が大 きい場合に判別される。B(膨らみ)は道路幅員に関係なく判別され る。 $\mathrm{D}$ (迫り出し), $\mathrm{G}$ (分断) $\mathrm{W}=7.0 \mathrm{~m}$ の判別回数が多く, 道路幅 員が小さい場合に判別される。

（4）後退高さ／建物高さ変化と空間形状意識

$\mathrm{A}($ (一様)は $\mathrm{l} / \mathrm{h}$ が変化してもほほ同数の判別回数である。B(膨ら み)は $l / h=0.33$ の判別回数が若干少ない。また $, 1 / h=0.33,0.40$, 0.50 では B I の判別回数が多いが, $l / h=0.60,0.67$ では B II の判別


合に判別される。 $1 / h=0.60$ では C II の判別回数が C I より多い。 $\mathrm{D}$ (迫り出し)は $1 / h=0.33$ の判別回数が少ない。 $l / h=0.60$ では D II の 判別回数がD I より多い。G(分断) $\mathrm{I} I / h=0.60$ の判別回数が多く, G II の判別回数がG I より多い。断面形状のみに注目すると，後退 高さ $(1$ )が $3.5 \mathrm{~m}$ である $1 / h=0.33$ は I (張り出し部を意識する)の判別回 数が多い。また，後退高さ ( 1 )が $10.5 \mathrm{~m}$ である $/ / h=0.60$ は II (張り出 し部を意識しない)の判別回数が多い。後退高さ $(1)$ が $7.0 \mathrm{~m}$ である $1 / \mathrm{h}$ $=0.4 ， 0.5 ， 0.67$ は $1 / h$ 大゙大いほど II $の$ 判別回数が多くなる。

(5) 空間形状意識の判別傾向

\begin{tabular}{|c|c|c|c|c|c|}
\hline \multicolumn{3}{|c|}{} & & \\
\hline
\end{tabular}

図 8 実験 (その 2$)$ 対象パターン

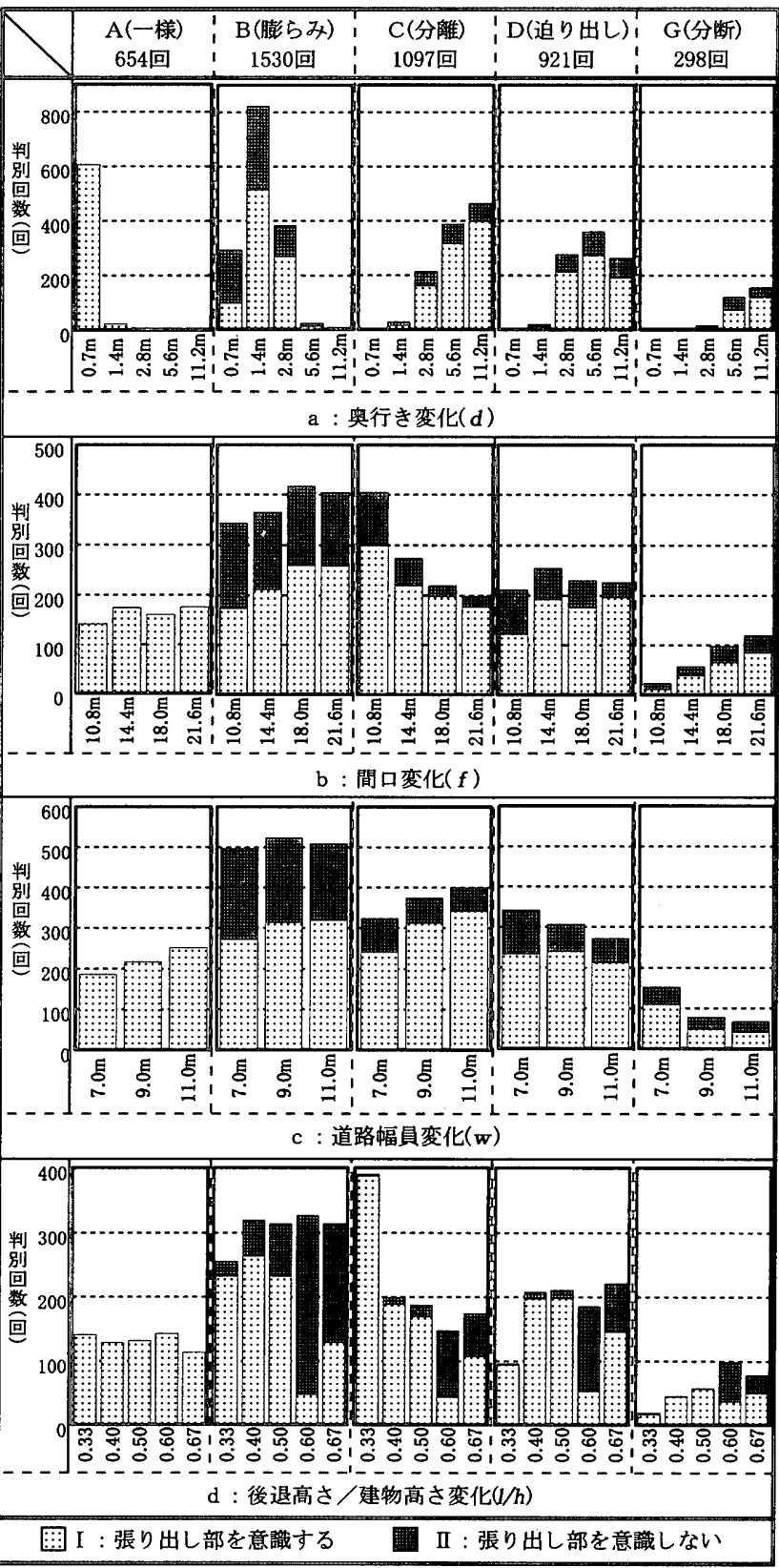

図 9 物的条件別の空間形状意識

表 1 は空間形状意識別に判別傾向をまとめたものである。空間形 状意識の平面形状では奥行き変化 $(d)$ で $\mathrm{C}$ (分離)と $\mathrm{G}$ (分断)が, 後退 高さ／建物高さ変化 $(l / h)$ で B(膨らみ)と D(迫り出し)が, 道路幅員 
変化 $(\mathbf{w})$ で $\mathrm{A}$ (一様)と $\mathrm{C}$ (分離)， $\mathrm{D}$ (迫り出し)と $\mathrm{G}$ (分断)がそれぞれ 類似した判別傾向を示している。また，空間形状意識の断面形状は 後退高さが $3.5 \mathrm{~m}$ の場合 I (張り出し部を意識する), $10.5 \mathrm{~m}$ 場合 II

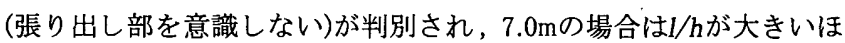
ど II が判別される傾向がある。空間形状意識の判別傾向を比較する と, 判別傾向がすべて一致する空間形状意識は存在しない。従っ て, 各物的条件を組み合わせることにより空間形状意識を予測する ことが可能であると考えられる。

\section{4. 空間形状意識の判別予測}

物的条件を組み合わせ，建物下層部が壁面後退した場合の街路空 間の物的条件と形状意識の相関関係を捉えることにより判別予測を 行う。

\section{1 判別予測の方法}

街路空間の規模を示す道路幅員と下層部壁面後退空間を構成する 物的条件である間口，奥行き，後退高さの比をとることにより規模 の異なる街路において空間形状意識の判別予測が可能になる。ま た，後退高さが空間形状意識の断面形状に影響を及ぼすと考えられ る。そこで判別予測の指標として, 間口／道路幅員 $(f / w)$, 奥行き／ 道路幅員 $(d / w)$, 後退高さ/道路幅員 $(l / w)$ と後退高さ $(1)$ の 4 変数を 選定した。 $d / w$ と $f / w, d / w と l / w, f / w と l / w$ を組み合わせ, 後退高さ 別に物的条件と空間形状意識の相関関係を捉え判別予測を行う。判 別予測の手順は, 縮尺模型実験の各対象パターンごとに最も多く判 別された空間形状意嬂の 7 割以上の判別回数を持つ空間形状意識を サンプルとして抽出する。そして各サンプルの物的条件より $d / w$ ， $f / w, l / w$ を求め, 後退高さ別に散布図を作成する。散布図より空間 形状意識間の差を明確化する。

\section{2 空間形状意識の判別予測}

上記の手順をもとに $\mathrm{A}=54$ 個， $\mathrm{B} \mathrm{I}=57$ 個， $\mathrm{B} I \mathrm{I}=28$ 個， $\mathrm{C} \mathrm{I}=$ 54 個， C II =4個，D I $=22$ 個， D II $=4$ 個， $\mathrm{G} \mathrm{I}=7$ 個， $\mathrm{G} \mathrm{II}=2$ 個，計232個のサンプルが抽出され，散布図を作成した。

図10-aは，縋軸を $f / \mathrm{w}$ ，横軸を $d / \mathrm{w}$ とし後退高さ $(1)$ 別に各空間形 状意識のサンプルをプロットしたものである。

$\mathrm{A}$ (一様)は 1 及び $/ w に$ 拘わらず $/ w<0.1$ に分布している。
表 1 空間形状意識の判別傾向

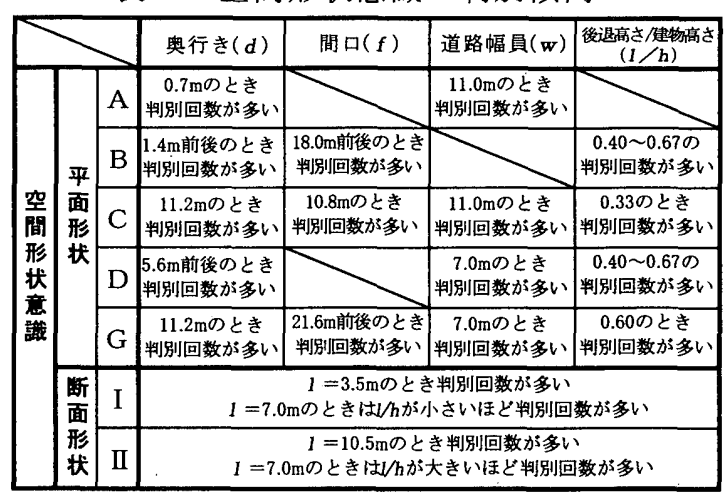

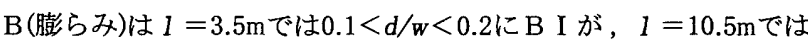
$0.1<d / \mathrm{w}<0.4$ に B II が分布している。 $1=7.0 \mathrm{~m}$ では $0.1<d / w<0.4$ に I ，II の形状意識が混在しているため, $1=7.0 \mathrm{~m} の \mathrm{~B}$ のンプ ルで縦軸 $l / \mathrm{w}$ ，横軸 $d / w$ とした散布図(図10-b)を作成した。 $1<4 d に B$ I ，1>4dに B II が分布している。

$\mathrm{C}$ (分離)は $l=3.5 \mathrm{~m}$ では $0.2<d / w$ に分布している。 $1=7.0,10.5 \mathrm{~m}$ では $d / \mathrm{w}>0.4 に \mathrm{C}$ (分離)だけでなく $\mathrm{D}$ (迫り出し)及び $\mathrm{G}$ (分断)が混在 している。そこで一次式 $f=d+w を ~ I=7.0 \mathrm{~m}$ 図中に入れること でこれらの形状意識の差があらわれる。 $f=d+w$ は後退空間と前 面道路部分の平面形状の関係を表しており奥行きと道路幅員の和が 間口と等しい場合, 即ち後退空間と前面道路部分の平面形状が正方 形である場合を示している。 $f<d+w$ (奥行きと道路幅員の和が 間口に対して大きい場合）にC I ，D II が，f>d+w（奥行きと 道路幅員の和が間口に対して小さい場合）にD I， G I が分布して いる。C，DとGの差を明確にするため， $1=7.0,10.5 \mathrm{~m}$ のC， $\mathrm{D}, \mathrm{G}$ のサンプルで縌軸 $1 / \mathrm{w}$ ，横軸 $f / w$ とした散布図(図10-c)を作成

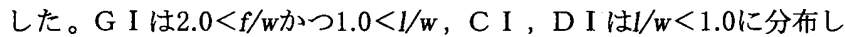
ている。また $1=10.5 \mathrm{~m}$ ときは図10-aでは $d / \mathrm{w}>0.4$ に C II , D II ， G II が分布しており，さらに図10-cより G II は2.0<f/wかつ1.0 $<1 / w ， C$ II ，D II はf $/ w<2.0$ かつI/w $>1.0$ に分布している。この場 合 C II ，D II の差はサンプル数が少ないためほとんど読みとれな い。



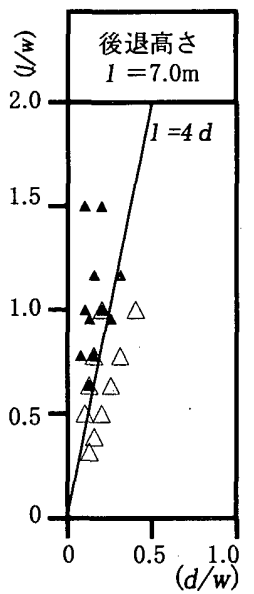

b : $(d / w) \times(/ / w)$

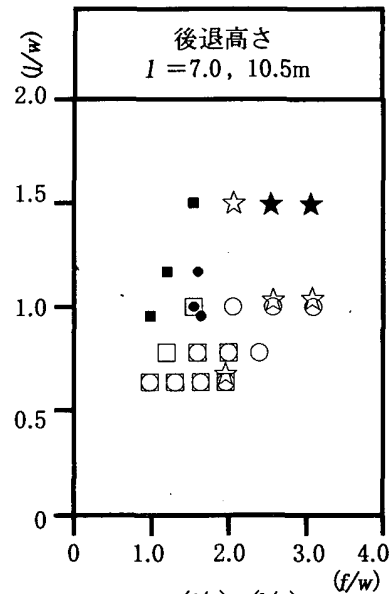

$c:(f / w) \times(V / w)$

図10 物的条件と空間形状意識の関係 
4.3 建物全層が壁面後退した街路空間の形状意識との比渂

建物の全層壁面が後退した街路空間と建物の下層部壁面が後退し た街路空間の形状意識の比較を行う。壁面全層が後退した街路の空 間形状意識は前稿 ${ }^{211}$ によって明確化されており，下層部壁面後退 がある街路の空間形状意識の平面形状と一致している。しかし，全 層壁面が後退した街路空間では下層部壁面が後退した街路空間で判 別される空間形状意識の断面形状の変化はみられない。(図11)

図12は本稿4.1 と同様の方法で作成した全層壁面が後退した街路 空間の形状意識の散布図である。図10-a の後退高さ7.0mの各空間形 状意識の分布範囲をこの散布図に入れると全層壁面が後退した街路 空間の形状意識と下層部壁面が後退した街路の形状意識の平面形状 がほぼ同様の物的条件で判別されているのが分かる。また，図10-a において後退高さ $7.0 \mathrm{~m}$ ときにா(張り出し部を意識しない)の分布 がみられることより，街路空間の垂直方向への意識の範囲は $7.0 \mathrm{~m}$ 前後であると考えられる。

\section{4 空間形状意識の判別予測図}

図13は $d / w, f / w ， l / w$ を指標とした散布図の分布形態より得られ た空間形状意識の判別予測図である。縮尺模型実験での後退高さ(l) は3.5,7.0,10.5mであり，これはそれぞれ建築物における1，2，3階 の階高に相当する。この判別予測図は道路の中央部が歩行可能であ り街路の両側建物の壁面高が等しく後退空間が矩形の街路空間で適 用可能である。

\section{5 . 現実空間での空間形状意識との比渂}

前章にて空間形状意識の判別予測を行った。ここでは現実の街路 空間において空間形状意識を判別させ，縮尺模型実験より得られた 判別予測との比較，検討を行う。

\section{1 実験方法}

実験は下層部壁面が後退した街路空間を被験者に自由に歩行・観 察させ形状意識を判別させた。歩道のある街路では道路中央部を歩

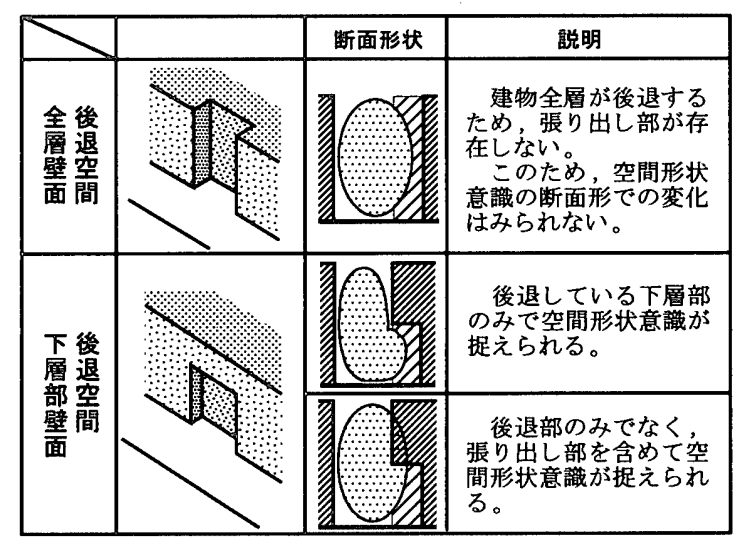

図11 全層壁面が後退した街路と下層部壁面が 後退した街路空間の形状意識の相違例

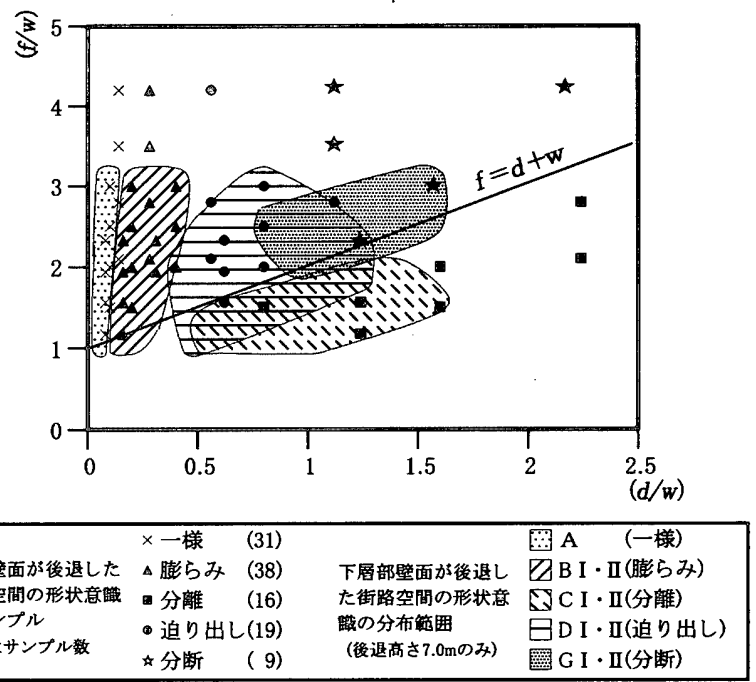

図12 全層壁面と下層部壁面が後退した 街路空間の形状意識と物的条件の比較

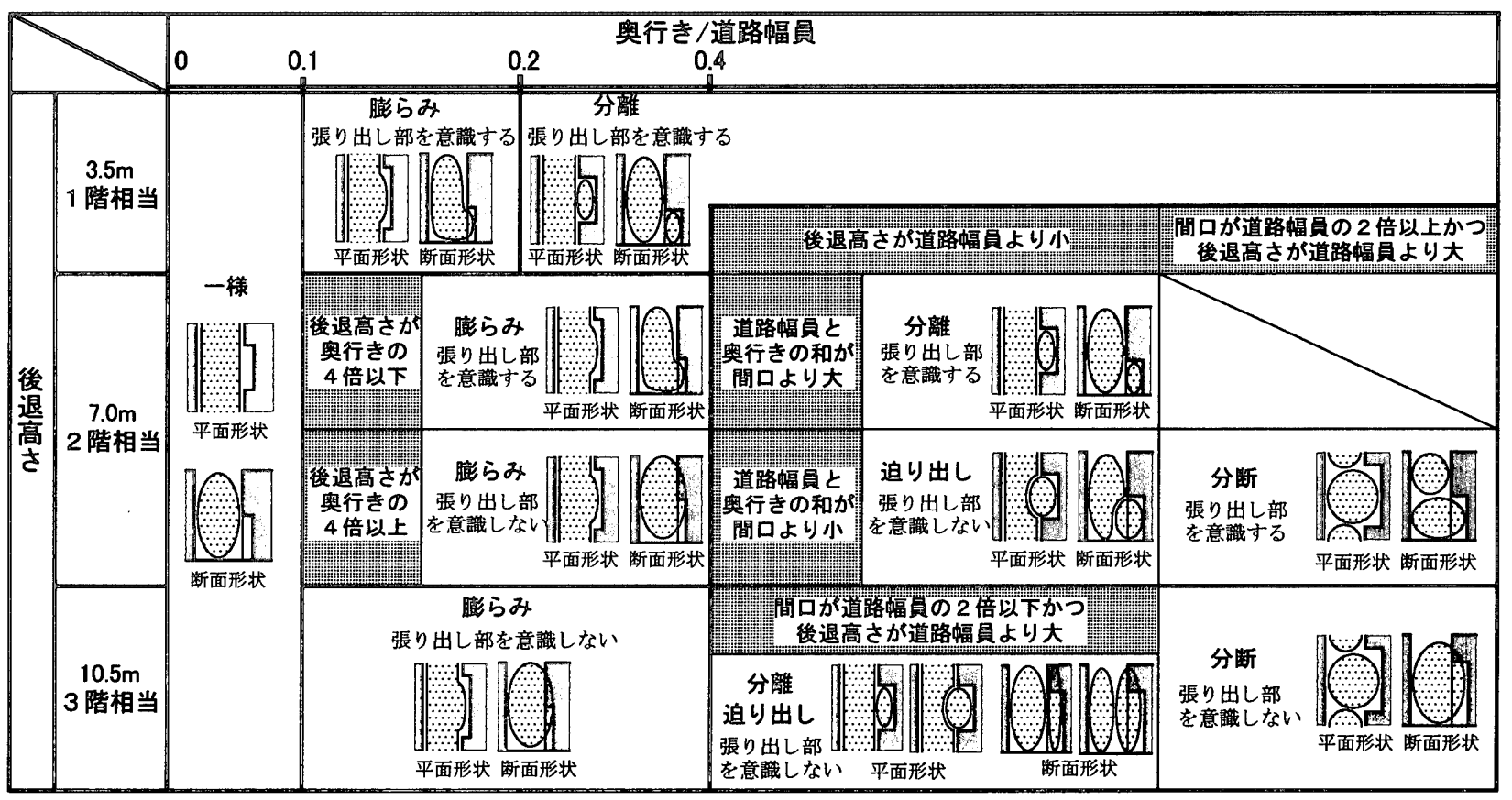

図13 街路空間の形状意識の判別予測図（建物下層部壁面後退の場合） 
行できないため歩道を歩行させた。その際，道路幅員をどのように 認識して形状意識を捉えたのかも記入させた。(図14) 被験者は名 古屋工業大学社会開発工学科学生・大学院生 13 名で, 6,7 名ずつ 2 グループに分けて行った。実験は2000年11月21,22日に行い，天候 は両日ともうす量りであった。

\section{2 実験対象地の選定}

現地踏查により名古屋市中区栄において歩道のある街路において 30 ，昭和区北山本町周辺において歩道のない街路において 100 計 40 の下層部壁面後退空間を抽出した。抽出したすべての下層部壁面後 退空間と道路幅員の測量を行ったのち，縮尺模型実験より得られた 判別予測をもとに空間形状意識を予測した。

\section{3 判別予測結果と現実空間の空間形状意識の比較}

図15は空間形状意識別の判別回数と判別予測結果の一致率を示し たものである。歩道のある街路では道路幅員の捉え方が被験者・対 象街路空間ごとに異なっている。これは対象街路空間に路面のテク スチャーやガードレール, 街路樹などの車道と歩道を分離する要因 があり被験者ごとに認識のされ方が異なるためと考えられる。

現実空間では道路幅員に比べ間口が大きい下層部壁面後退空間が 少ないため $\mathrm{D}$ (迫り出し)， $\mathrm{G}$ (分断)と予測される空間が少ない。判 別予測結果と現実空間における判別回数を比較すると，歩道のない 街路では判別予測結果と判別実験の一致率は高い。歩道のある街路 では一致率が若干低いが，これは(1道路全体を道路幅員とした場 合，道路中央部を歩行できない，(2)歩道のみ・車道までを道路幅員 とした場合は後退部の向かい側に壁面が存在しない ためであると 考えられる。

空間形状意識別の一致率は $\mathrm{A}$ (一様)，C(膨らみ)の一致率は70\%前 後と高い值を示している。しかし，B(膨らみ), D(迫り出し), G (分断)の一致率は若干低い。これは, 路面や後退空間のテクスチャ 一や色などにより街路部と後退部とがそれぞれ独立した空間を持つ 形状意識は認識されやすく, 街路部と後退部の両方にまたがる空間 を持つ形状意識は認識されにくいためであると考えられる。しか し, 道路の中央部が歩行可能であり両側壁面が存在する街路空間に おいて一致率は高く，縮尺模型実験の判別予測は有効であるといえ る。

\section{6.まとめ}

以上の分析より得られた結果は，以下の通りである。

（1）建物下層部の壁面後退による街路の空間形状意識にはA：一 様, $\mathrm{B}:$ 膨らみ, $\mathrm{C}:$ 分離, $\mathrm{D}:$ 迫り出し, $\mathrm{G}:$ 分断 がある。上 層の張り出し部が影響する $\mathrm{B}, \mathrm{C}, \mathrm{D}, \mathrm{G}$ の形状が断面において I : 張り出し部を意識する，II：張り出し部を意識しない に分か れ, 合計 9 種類になる。

（2）空間形状意識 9 種類と下層部壁面後退空間の物的条件 (間口 $(f)$ ，奥行き $(d)$, 道路幅員 $(w)$, 後退高さ $(1)$, 建物高さ $(h))$ との 関係を求め, 判別予測図を作成した。これにより空間形状意識の判 別予測が可能となった。

（3）建物の全層壁面が後退した場合と，下層部壁面が後退した場合 との街路空間の形状意識は，平面形状ではほぼ同様である。断面形 状では, 後退高さが $7 \mathrm{~m}$ 前後を境として, 高さがそれ以下の場合上 部の張り出しを意識する傾向が見られる。

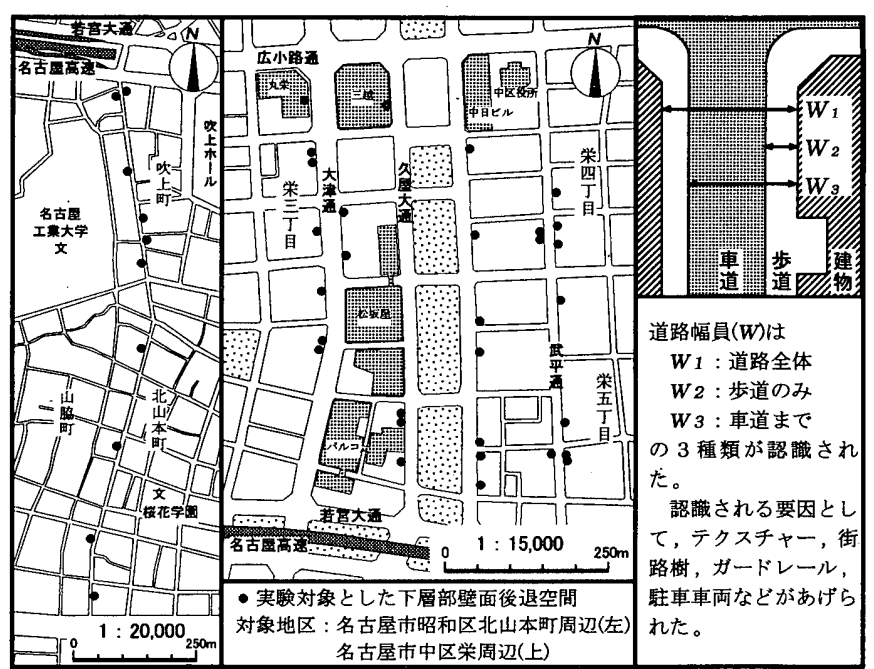

図 14 実験対象地区と道路幅員の認識形態

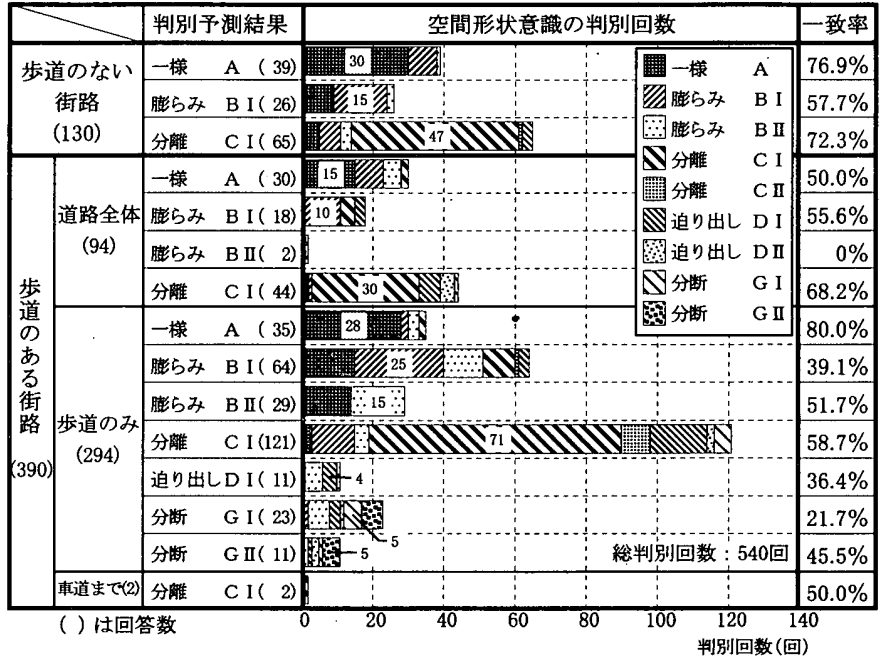

図15 空間形状意識の判別回数と判別予測の一致率

（4）縮尺模型実験の物的条件の変数は間口，奥行き，道路幅員，後 退高さ，建物高さであり，これらの変数に基づき判別予測図を作成 したため,これらの值が示す範囲内において有効である。

（5）縮尺模型実験には極めて単純化した街路空間を用いているが， このVTR映像による実験データにより得られた判別予測図が現実空 間においても高い一致率を得ている。これより模型空間においても 空間形状の把握が十分可能である。

（6）判別予測図は，現実空間での判別実験により(1)道路中央部を歩 行できない, (2)後退部の向かい側に壁面が存在しない 街路空間に おいて適用するには疑問が残る。しかし，道路の中央部が歩行可能 であり両側壁面が存在し後退空間が矩形である街路においては適用 可能であると考えられる。

注

本論文は1996年度日本建築学会大会学術講演会に発表した参考文献 1 ) の 内容をさらに実験調查を加え発展させたものである。

1) 参考文献 2 ) を参照

2 ) 透視図実験の実験対象パターンは, 名古屋市およびその周辺都市の 4 地 区において行った現地踏査による下層部壁面後退空間の測量結果にもと づ決定した。 
3 ）その他の内訳は，回答数が 1 である空間形状意識が 5 種䅡で 5 回答，同 一の被釦者が回答した I，II以外の断面形状が 2 種類で 5 回答あり，回 答数が合計10となっている。従って，得られた形状意識は $\mathrm{A} \sim \mathrm{G}$ IIまで の 12 種類とその他の 7 種類の合計 19 種類であり, その他の回答数が 10 と なっている。

4 ）1996年に開発したビジュアルシミュレータであり，被験者がノブ操作に より縮尺模型空間を水平・垂直移動，水平・垂直回転しながら自由に観 察することができるコンピュータ制御のシミュレーションシステムであ る。詳細は，参考文献 8 ) を参照されたい。本実験では1/50スケールに おいて視点高さ $1.5 \mathrm{~m} に$ 相当する $3 \mathrm{~cm}$ より撮影を行った。

5 ) 空間形状意識実験において, 各被験者が知覚した提示実験対象パターン の空間形状意識が 12 空間形状意識のどれに相当するのかを判別させて おり，判別回数とはこれらの回答数を集計したものである。本研究では 各実験において実験対象パターン×被験者数が全判別回数となる。

6 ）道路幅員変化を 3 パターン加えたための実験対象パターンの增加に伴い 被鈳者への負担が考えられるため, 空間形状意識実鈳（その1）の実験 結果より比皎的判別傾向の差が表れていない間口，後退高さ／建物高さ 変化についてはそれぞれ7.2m，0.75を除いた。また，判別傾向に差が表 れると考えられる奥行きに新たに $0.7 \mathrm{~m} を$ 加えた。

\section{参考女㣮}

1 ）石川 整, 松本直司，山内比呂史: 建築の下層階部分が壁面後退した場 合の街路空間形状意識一街路の空間形状意識に関する研究(その 4)-
日本建築学会大会学術講演梗概集, pp.681 682, 1996.9

2 ）松本直司，藤井勝彦，張 奕文，若山 滋: 壁面後退による街路の空間 形状意識について一街路の空間形状意識に関する研究一, 日本建築学会 計画系論文報告集，第474号, pp. 115 122，1995.8

3 ) 藤井勝彦, 松本直司 : 壁面後退による街路の空間形状意識についてー街 路の空間形状意識に関する研究(その 1 )一，日本建築学会大会学術請演 梗概集，pp.1101〜1102，1994.9

4 ) 近藤 崇, 松本直司, 藤井勝彦: 壁面後退空間の高さ変化と空間形状意 識一街路の空間形状意識に関する研究(その 2)一，日本建筑学会大会学 術譚演梗概集, pp.1103 1104，1994.9

5 ) 山内比呂史, 松本直司, 藤井勝彦 : 壁面後退街路の步車道境界を考盧し た空間形状意識一街路の空間形状意識に関する研究(その3)一，日本建 築学会大会学術請演梗概集, pp.871 872，1995.8

6 ) 松本直司, 佐々木太朗, 谷口汎邦: 二棟平行配膡空間の視覚的まとまり についてー建築群の空間構成計画に関する研究・その $7-$, 日本建築学 会計画系論文報告集，第446号, pp.111 118，1992.2

7 ) 松本直司, 野田喜之, 張 奕文, 谷口汎邦 : 二棟・三棟配圈の空間構成 における建物まわりの視覚評価予剆一建築群の空間構成計画に関する研 究・その 8-, 日本建築学会計画系論文報告集, 第456号, pp.153 $162,1994.2$

8 ) 瀬田, 松本他 : 知覚行動直結型ビジュアルシミュレータの開発, 日本建 築学会技術報告集, No.4, pp.92〜96, 1997.3 